\title{
The impact of Greenfield investment on domestic entrepreneurship
}

\author{
Tung Son $\mathrm{Ha}^{1}$, Vu Tuan $\mathrm{Chu}^{1,2^{*}}$, Mai Tuyet Thi Nguyen ${ }^{1}$, Dung Hoai Thi Nguyen ${ }^{1}$ and Anh Ngoc Thi Nguyen ${ }^{1}$
}

\author{
* Correspondence: vutuanchu@ \\ gmail.com \\ ${ }^{1}$ Faculty of Business Management, \\ National Economics University, \\ Hanoi, Vietnam \\ ${ }^{2}$ Telfer School of Management, \\ University of Ottawa, Ottawa, \\ Canada
}

\begin{abstract}
The FDI-entrepreneurship nexus has received growing attention over the last decade. However, the empirical findings on their relationship have been inconsistent at best. This study seeks to examine how the inflows of Greenfield investment influence entrepreneurship of the host country. Using panel data from 110 countries during the period 2001-2018, we find that growing level of Greenfield investment brings detrimental impact on the level of total and opportunity-driven entrepreneurial activities in the host countries while the impact on necessity-driven entrepreneurship have been mixed. The results regarding the impact of Greenfield investment on total entrepreneurial activities and opportunity-based entrepreneurial activities are robust across different econometric settings, different time span, and different categories of control variables.
\end{abstract}

Keywords: Greenfield investment, Entrepreneurial activities, Opportunity-based entrepreneurship, Foreign direct investment

\section{Introduction}

Only in recent decades that entrepreneurship has been considered as the main engine of economic development and entrepreneurs as the national assets to be cultivated, motivated, and remunerated to the greatest possible extent (Albulescum \& Tămăşilă, 2014). Entrepreneurs drive innovation, deliver improved products, and develop new markets but too much entrepreneurship can cause damaging effect to economic development (Gromb \& Scharfstein, 2002). One of the most well-known puzzles in management is the stylized fact that entrepreneurship level varies systematically across countries and across different time periods (Gromb \& Scharfstein, 2002). Thus, the origins and determinants of entrepreneurship are the topic of wide spectrum of explanations and theories. Even though increasing number of scholars have made attempts to establish a comprehensive framework on the determinants of entrepreneurship (Brock \& Evans, 1989; Gavron et al., 1998), an understanding of cross-variations in entrepreneurship at the macro level is still limited.

Foreign direct investment (FDI) is regarded as one of the most important contributors of economic growth (Ahmeti \& Kukaj, 2016). Foreign direct investment cannot only be a key driver of development when tuning the economy but can also be

(c) The Author(s). 2021 Open Access This article is licensed under a Creative Commons Attribution 4.0 International License, which permits use, sharing, adaptation, distribution and reproduction in any medium or format, as long as you give appropriate credit to the original author(s) and the source, provide a link to the Creative Commons licence, and indicate if changes were made. The images or other third party material in this article are included in the article's Creative Commons licence, unless indicated otherwise in a credit line to the material. If material is not included in the article's Creative Commons licence and your intended use is not permitted by statutory regulation or exceeds the permitted use, you will need to obtain permission directly from the copyright holder. To view a copy of this licence, visit http://creativecommons.org/licenses/by/4.0/. 
considered a predicament in relation to the entry and performance of domestic companies (Apostolov, 2017). FDI into a host country can take a wide variety of forms in manufacturing, assembly, or services such as mergers and acquisitions, Greenfield investment, and extension of domestic capital. Each type of FDI not only brings distinctive benefits to the host countries' growth and welfare but also offers corresponding distinctive threats and damages (Moran, 1998). As a consequence, it is logical to deduce that each market entry mode exerts a distinctive impact on the domestic entrepreneurial activities.

Schumpeter (1942) has shown that entrepreneurship and new firm creation are the engines of economic growth and development. Domestic entrepreneurship and foreign direct investment refer to two distinctive ways on how new firms are created (Ayyagari \& Kosová, 2010), thus both being classified as different types of investments into the host countries. The relationship between FDI and entrepreneurship suggests a substitution effect such that entrepreneurship provides an alternative way of doing business to attracting investment from foreign investors.

Significant efforts have been made in finding the linkages between entrepreneurship and foreign direct investment. Most existing studies have pooled mergers and acquisitions (M\&A) and Greenfield investment (Greenfield) together into one group of FDI in investigating the impact of FDI on local firms. However, the conclusions that these studies come to are highly questionable. First, the composition of FDI inflows into the host countries is dominated by M\&A. In addition, Calderon et al., (2002) emphasizes the acquisition of existing assets $(\mathrm{M} \& \mathrm{~A})$ has been growing more rapidly than the investment in new assets (Greenfield). However, the distinctiveness of Greenfield has been largely neglected by scholars when making the link between FDI and entrepreneurship. Second, despite their similarities, Greenfield and M\&A carry certain distinct differences (Raff et al., 2009). First and foremost, while M\&A involves the transfer of asset ownership, Greenfield depends solely on firms' own capacities, which are linked to host countries' intrinsic attributes (Davies et al., 2015). Next, Greenfield involves high investment costs and highly risky (the riskiest type of foreign direct investment), making it the less popular type than mergers and acquisitions (Muller, 2006). In other words, Greenfield investment bears more similarities to entrepreneurship than M\&A does. In that light, one question may arise: Whether Greenfield investment crowds in or crowds out domestic entrepreneurship?

Theoretically, foreign direct investment is expected to generate the impact of technology and knowledge transfer, improve competitiveness, productivity and long-run growth of the local economies (Guimón, 2009; Blonigen \& Piger, 2011). However, the empirical literature is far from universal on the effects of FDI. Recently, an increasing number of papers have examined the connection between FDI and new local firms' entry and survival (De Backer \& Sleuwaegen, 2003; Ayyagari \& Kosová, 2010; Munemo, 2015; Danakol et al., 2016). The first strand of literature suggests that the positive spillover effects would increase the productivity of domestic firms, enhance domestic investment and firms' entry (De Mello, 1999; Munemo, 2015). Another strand offers a substitution effect in the sense that domestic investment is crowded out by the same amount of foreign investment, forcing the exit of local firms and deterring the entry of new firms. In short, existing empirical literature offers inconsistent predictions on the entrepreneurship-FDI connection. Amoroso and Muller (2018) argue that the 
relationship between FDI and entrepreneurship is established based on a complex framework that involves new ventures' regulations (Munemo, 2015) and horizontal and vertical industry spillovers (Markusen \& Venables, 1999). Another reason for the unanimous finding is that the impact of FDI on entrepreneurship hinges on the types of FDI such as Greenfield (new foreign firm) or Brownfield (M\&A or foreign acquisition of local firms). Traditional literature associated Greenfield with positive impact such as employment generation or capital formation while mergers and acquisitions have been criticized for their speculative motives or value destruction (Norbäck \& Persson, 2005; Johnson, 2006; Ashraf, Herzer, \& Nunnenkamp, 2016).

Previous empirical findings have typically focused on the impact of either overall FDI inflows or cross-border M\&As on entrepreneurship and local economies. Amoroso and Muller (2018) are the first to examine the relationship between knowledge intensive Greenfield investment and local firm entry and survival. However, their study is limited to the context of European countries and knowledge intensive FDI and does not address the influence of Greenfield on entrepreneurial activity. Another reason for the underinvestigation of studies on Greenfield is the lack of reliable data on Greenfield. This gap is theoretically intriguing because we expect that the impact of Greenfield on domestic entrepreneurship differs from M\&A and diverges among different countries.

In this paper, we use a comprehensive dataset on Greenfield investment from the World Investment Report online database that allows us to explore the under-investigated impact of Greenfield FDI on the rate of entrepreneurial activity in the host countries. We constructed a country-level panel dataset by matching information on Greenfield FDI inflows to the rate of national entrepreneurial activity and additional macroeconomic control variables from GEM and World Bank Database. The first contribution is the extensive coverage of all available countries around the world in a strongly balanced panel from 2001 to 2018. The second contribution is the disentanglement of FDI inflows into Greenfield investment in predicting the rate of entrepreneurial activity. Most previous studies investigated the linkage between FDI and domestic entries or survivals without taking into consideration entrepreneurs who operate the daily business and entrepreneurial activities (Albulescum \& Tămăşilă, 2014). The TEA variable measures the proportion of the working population who bears the intention to pursue entrepreneurial activities. Finally, most research scholars seem to show their approval for the positive impact of Greenfield investment such as R\&D stock or knowledge intensive Greenfield. Our paper will offer another interesting insight into the impact of Greenfield investment on domestic investment and domestic entrepreneurship. Our analysis will be also split and tested in pre- and post-crisis as for robustness checks. The remainder of the paper is the following. The "Literature review" section presents a brief overview of the literature on entrepreneurship and FDI. The "Methodology and empirical results" section describes the stylized facts, the data, and the methodology. The "Empirical results and discussion" section highlights the empirical findings. The last section concludes.

\section{Literature review}

\section{Greenfield investment}

Foreign direct investment (FDI) can take two very different forms: Greenfield investment, which involves the creation of a new facility, or mergers and acquisitions (M\&A), 
which involve the purchase of assets of existing domestic firms (Ashraf 2014). The origin of Greenfield investment comes from the fact that a multinational company builds a newly-developed venture from the ground up by plowing and prepping an entire green field. Unlike Brownfield investment (or M\&A) that leases existing assets and facilities and transforms them to adapt to their needs, Greenfield investment involves building everything from the scratch, and investors exert the highest degree of control over the facilities and land of the sponsoring company. Greenfield investment as a strategic choice of expansion is referred to as setting up a start-up, employing local employees, and adapting to the domestic institutional environment (Alon, Elia, \& Li, 2020). Greenfield investment is more popular in relation-based countries that give support to the full control and protection over the investment of the investors (Alon et al., 2020; Wu, Li, \& Selover, 2012). Greenfield investment and M\&A are fundamentally different on the ground that Greenfield investors use their own technology, capital, and intellectual property (Hennart \& Park, 1993).

Harms ad Méon (2018) shows that Greenfield FDI has a significantly positive effect on economic growth. This finding is robust across various definitions of Greenfield FDI and different categories of subsamples. Specifically, the direct positive impact on growth of Greenfield is realized through means of physical capital accumulation and additional production capacity (Ashraf et al., 2016). However, not all empirical results support the beneficial impacts to the host country's economy. One of the muchdiscussed questions is whether Greenfield FDI crowds in or crowds out investment from domestic sources. Studies by Ashraf et al. (2016) and Calderón et al., (2002) both draw attention to the significant crowding-out effect of Greenfield investment that damages long-term economic growth. In general, FDI can crowd out domestic investment if foreign firms finance their investment through borrowing in the host country, thus increasing the host country's interest rate (Harrison \& McMillan, 2003). Crowding-out may also occur if foreign firms "steal" market share from domestic competitors (Aitken \& Harrison, 1999) and if foreign firms purchase fewer inputs locally than the domestic firms they displace (Rodriguez-Clare, 1996). On the other hand, an increase in FDI can lead to an increase in domestic investment if FDI stimulates new domestic investment through forward and backward linkages (UNCTAD, 1999). Calderón et al. (2002) and Jude (2018) find that M\&A leads to the crowding-in effect of domestic investment, especially if the countries have developed financial markets.

\section{Entrepreneurship}

Many researchers and scholars have arrived at different definitions for entrepreneurship (Hébert \& Link, 1989). In linking entrepreneurship and foreign direct investment at the macro level, entrepreneurship has been classified as "the creation of new organizations" (Gartner, 1989) and "prime movers of innovation" (Harbison, 1956). Hébert and Link (1989) define entrepreneur as a person who creates, organizes, and operates a new start-up. A firm start-up is one of the major forms of entry to the market. Start-ups are formed and influenced by both micro and macro factors. Audretsch (1994) documented several characteristics of entrepreneurship at the macro level. First, there are considerable differences in the rate of entrepreneurship across industries. Second, the rate of entrepreneurial activity fluctuates significantly year to year. Third, the impact of 
entrepreneurship on economic development is not similar among different countries. Entrepreneurship's possible impact on the economy has been investigated extensively over the last two decades (Neumann, 2020). Regarding the antecedents of entrepreneurship, most previous studies have focused on the micro determinants of entrepreneurship while a fair number of studies have also revealed the macro determinants. Some of the popular macro antecedents of entrepreneurial activity include demandside factors (Gemmell, 1982; Solow, 1956), supply-side factors (Rudra, 2002), cultural factors (Hofstede and Minkov 2010), and quality of governance (Kaufmann \& Kraay, 2007). Most of those antecedents have been conceptual and need empirical validation (Thai \& Turkina, 2014). Our study highlights another macroeconomic antecedent of entrepreneurship that originates from the foreign source.

According to Lankes (2011), innovation is defined by entrepreneurship. Entrepreneurship effectuates innovation by putting new ideas and inventions into practice with the infusion of human resources, capital resources, and institutional resources (Crumpton, 2012). Entrepreneurs are those whose functions it is to carry out those combinations (Schumpeter, 1934). Dess and Lumpkin defines the term "innovativeness" as tendency of the firms to engage in new inventions, experimentation, and creative processes that result in new technological and product innovation. The role and contribution of technological and product innovation to economic development and national growth have been well established in the literature (Solow, 1956; Romer, 1986). Economic growth that is endogenously determined by technical change has just recently been investigated by scholars. Romer (1990) proposes a new class of endogenous growth model that includes the proxy for entrepreneurship by modeling the process of innovation and motives of invention from the macroeconomic level. Grossman and Helpman (1991) and Aghion and Howitt (1992) develop productivity growth models that emphasize the role of knowledge, knowledge spillovers, and technological substitution in the process of economic growth.

\section{Greenfield investment and entrepreneurship}

We have shown that entrepreneurship is an essential engine for economic growth and development and entrepreneurs are prime movers of innovation (Harbison, 1956). Establishment of enterprises leads to an increase in employment avenues both directly and indirectly. Entrepreneurship has a French origin which refers to the creation or extraction of value. With this definition, entrepreneurship is viewed as change, which may include other values than simply economic ones. Therefore, entrepreneurship is known to involve high risks associated with launching a startup. Given the importance of entrepreneurship in socio-economic aspects, a number of studies have investigated the determinants of entrepreneurship. However, the influence of FDI and especially Greenfield on entrepreneurship has been largely ignored in the literature.

It is also important to distinguish Greenfield investment from M\&A. Harms and Meon (2018) demonstrate that, in contrast to Greenfield FDI, a larger volume of M\&A results in an appreciated real exchange rate. The resulting loss in price competitiveness may explain the poor growth effect of the M\&A variant of FDI. Existing literature on the economic consequences of Greenfields and M\&As has pointed out the possifbility that Greenfields would contribute to increasing the recipient's capital formation and 
productivity, while M\&As may not (Kim, 2009). This is because, whereas Greenfields involve the direct investment and construction of new facilities, cross-border M\&As involves the transfer of the recipient country's income to the home market. As a result, M\&As might not lead to any capital formation and/or productivity enhancement of the host country. Danakol et al. (2016) reveal that the FDI inflows via M\&A act to crowd out and reduce domestic investment at the level of the host economy and within sectors. The effect however is modest in scale; at the economy-wide level, a $10 \%$ increase in M\&A FDI inflows as a share of GDP is associated with a $0.19 \%$ decline in domestic entrepreneurship. The reason has something to do with the fact that foreign firms can attract scarce domestic resources for example talented and skilled workforce. This translates into additional competitive pressure in labor markets, with the potential to change the entrepreneurial landscape in the local economy. If local enterprises fail to adopt the superior technology, they will be forced to exit.

Previous literature has focused on the nexus between the total entrepreneurial activity and aggregate foreign direct investment. Most papers linking entrepreneurship and FDI are based on the theories of spillovers effect and crowding out effect (De Backer \& Sleuwaegen, 2003; Knoben, Ponds, \& Oort, 2011; Pathak, Laplume, \& Xavier-Oliveira, 2015). Danakol et al., (2016) and Stiebale and Reize (2011) are few of the studies that examine the influence on entrepreneurship, a specific category of FDI, which is mergers and acquisitions. On the other side, a large proportion of literature has been devoted to the identification of the determinants of entrepreneurship (Ayyagari \& Kosová, 2010), some of which are macroeconomic fundamentals, quality of institutions, and commercial infrastructure. The FDI-entrepreneurship relationship was first investigated by Kim and $\mathrm{Li} \mathrm{(2012)}$ and the literature has produced mostly contradictory results. Theoretical arguments suggest that Greenfield investment could have both positive and negative impact on entrepreneurship.

New waves of foreign Greenfield firms entering the host countries could lead to the diffusion of new technology management practices and the creation of new subcontracting opportunities (Albulescum \& Tămăşilă, 2014). This is supported by the research of Javorcik (2004) that domestic entrepreneurship may be expected to gain benefits from knowledge spillovers or technology transfer beyond the actual undertaken project by new Greenfield.

Javorcik (2004) finds that the establishment of new Greenfield firms would generate new demands in the host countries by creating new entrepreneurial opportunities and allowing domestic firms to imitate and learn from their failures. Alternatively, firms established under Greenfield investment can produce what is called the demand creation effect, bringing new demand to the local markets, new opportunities, and higherquality products. Greenfield can also bring diffusion of new managerial skills to the domestic firms when trained employees move from foreign to indigenous firms for higher salaries or senior positions, they carry with them new management practices which they acquired in foreign firms (Fu, 2011).

Negative spillover effects can occur when Greenfield investment would crowd out domestic entrepreneurship through their selections in product and labor markets (De Backer \& Sleuwaegen, 2003). The presence of Greenfield would lead to increased competition for qualified employees in the product markets and labor markets (Balsvik \& Haller, 2011). Ayyagari and Kosová (2010) make reference to the effect of entry barrier 
by stating that the presence of foreign firms in an industry can discourage the entry of domestic firms by raising the technological barriers to entry. Being superior to the domestic counterparts, foreign Greenfield will capture the market demand and displace domestic firms out of business (Aitken \& Harrison, 1999). Additionally, newly established Greenfield would generally receive favorable incentives from the local government and authority, giving them unfair competitive edge over the local entrepreneurs.

On the other hand, domestic entrepreneurs may also suffer from negative spillover effects when the presence of multinational companies drive up the competition creates barriers to entry (Gorg \& Greenaway, 2004).

M\&A and Greenfield are completely different if we take into account the actual investment into the host countries (Gopalan et al., 2017). Unlike FDI via mergers and acquisitions, Greenfield investment refers to one mode of foreign entry via setting up a new venture (Muller, 2006). In addition, Greenfield investment would lead to the appearance of new entrepreneurial entities but M\&A involves the acquisition of existing local firms.

\section{Methodology and empirical results Data and methodology}

Data for the total early-stage entrepreneurial activity including necessity- and opportunity-driven entrepreneurship is obtained from the Global Entrepreneurship Monitor (GEM) while information about Greenfield is extracted from the World Investment Report (UNCTAD). Data about Greenfield obtained from UNCTAD ranges from 2005 to 2011. GEM information related to entrepreneurial activity is crosssectional data on 113 countries from 2001 to 2018. Our control variables are all acquired from either GEM or UNCTAD. Finally, our variables and data are gleaned, analyzed, and combined to generate a panel data that includes 695 observations of 113 countries for the period 2001-2018.

Table 1 provides the descriptive statistics of the variables used in the paper.

\section{Fixed and random effects}

The fixed-effect panel regression model is the preferred choice in evaluating the explanatory variables of entrepreneurial activity because the within model (or fixed effect) is able to disentangle the variations among different cross sections of countries (Albulescu \& Tămăşilă, 2013). However, we also include random model in the regression results because the number of countries $(T=113)$ is much higher than the number of years $(\mathrm{N}=18)$. A Hausman test is also utilized in order to compare and contrast between fixed-effect and random-effect equations.

The fixed effect panel model is usually used for assessing the entrepreneurship determinants. Fixed effects underline disparities between countries. A new development of this classical model is the panel negative-binomial model, which accounts for violations in the assumption of homoscedasticity and, in the same time, provides the flexibility to address unobserved heterogeneity (Hausman et al., 1984). Nevertheless, as Allison and Waterman (2002) show, this method does not, in fact, control for all stable covariates. We then test not only a simple fixed effect model but also a random model, having in mind the fact that the structure of our sample shows a $\mathrm{N}<\mathrm{T}$ situation (the number of 
Table 1 Descriptive statistics

\begin{tabular}{|c|c|c|c|c|c|c|}
\hline Name & Mean & $S d$ & Min & Max & Description & Source \\
\hline Gdpgrowth & 3.82 & 5.17 & $\begin{array}{l}- \\
62.1\end{array}$ & 123.1 & $\begin{array}{l}\text { GDP growth rate is expected to have positive influence on } \\
\text { either opportunity-based or necessity-based } \\
\text { entrepreneurship }\end{array}$ & $\begin{array}{l}\text { UNCT } \\
A D\end{array}$ \\
\hline Gdpcapita & 8.46 & 1.54 & 4.72 & 12.15 & $\begin{array}{l}\text { GDP per capita, transformed in natural log. Literature } \\
\text { suggests the impact is positive on the opportunity } \\
\text { entrepreneurship and negative on necessity } \\
\text { entrepreneurship }\end{array}$ & $\begin{array}{l}\text { UNCT } \\
A D\end{array}$ \\
\hline Ingreen & 6.81 & 2.65 & -1.61 & 12.41 & $\begin{array}{l}\text { Greenfield inward investment represents the stock volume } \\
\text { expressed in current US dollars, transformed in natural log. } \\
\text { Our analysis argues that it will have negative impact on the } \\
\text { total entrepreneurial activity }\end{array}$ & $\begin{array}{l}\text { UNCT } \\
A D\end{array}$ \\
\hline fof & 34.13 & 9.24 & 12.3 & 75.4 & $\begin{array}{l}\text { Fear of failure rate. Percentage of the } 18-64 \text { population who } \\
\text { agree that they see good opportunities but would not start } \\
\text { a business for fear it might fail. }\end{array}$ & GEM \\
\hline ei & 18.73 & 15.3 & 0 & 90.95 & $\begin{array}{l}\text { Entrepreneurial intentions. Percentage of } 18-64 \text { population } \\
\text { (individuals involved in any stage of entrepreneurial activity } \\
\text { excluded) who are latent entrepreneurs and who intend to } \\
\text { start a business within } 3 \text { years }\end{array}$ & GEM \\
\hline Opportunity & 7.9 & 5.35 & 0.81 & 31.89 & $\begin{array}{l}\text { Opportunity-driven entrepreneurship is the percentage of } \\
\text { those involved in total early-stage entrepreneurial activity } \\
\text { because they spot an opportunity in the market }\end{array}$ & GEM \\
\hline Necessity & 2.96 & 2.93 & 0.09 & 19.55 & $\begin{array}{l}\text { Necessity-driven entrepreneurship is the percentage of those } \\
\text { involved in total early-stage entrepreneurial activity who } \\
\text { have no other viable options for licit income }\end{array}$ & GEM \\
\hline Tea & 11.45 & 7.66 & 1.48 & 52.11 & $\begin{array}{l}\text { Total early-stage entrepreneurship is the percentage of } 18-64 \\
\text { population who are either a nascent entrepreneur or owner- } \\
\text { manager of a new business }\end{array}$ & GEM \\
\hline
\end{tabular}

countries is higher than the number of periods). In addition, for the robustness check, we do not have strongly balanced panels (lack of data for the beginning of the period) and the random-effects models address these aspects. In order to avoid the broken panel problem, when entrepreneurship data were missing (Germany - 2007; Ireland 2009; Sweden - 2008, 2009; and Switzerland - 2006, 2008), we have used the linear interpolation. Hausman test was performed in order to select the most appropriate model between the fixed and random effects. The general tested equations for fixed and respectively for random effects are:

$$
\mathrm{Y}_{\mathrm{i}, \mathrm{t}}=\beta_{0}+\beta_{1} \text { lngreen }+\beta_{2} \mathrm{X}_{i, t}+\alpha_{\mathrm{i}}+\mathrm{e}_{\mathrm{i}, \mathrm{t}}
$$

In which, $Y_{i, t}$ is the explained variable (tea, necessity, opportunity); lngreen represents Greenfield investment in natural $\log$ form; $\beta_{0}$ is the constant; $\alpha_{i}$ represents all the constant time-invariant characteristics of the countries; $X_{i, t}$ represents the vector of control independent variables; $\beta_{1}$ and $\beta_{2}$ are the coefficients; $e_{i, t}$ is the error term.

$$
\mathrm{Y}_{\mathrm{i}, \mathrm{t}}=\beta_{0}+\beta_{1} \text { lngreen }+\beta_{2} \mathrm{X}_{\mathrm{i}, \mathrm{t}}+\mu_{\mathrm{i}}+\mathrm{e}_{i, t}
$$

In which, $\mu_{\mathrm{i}}$ represents between-entity errors; $\mathrm{e}_{\mathrm{i}, \mathrm{t}}$ is the within-entity error.

\section{GMM estimated method}

Most of the previous studies conducted on the influence of foreign investment on domestic entries use panel data fixed/random effect models or least square dummy variable (LSDV) models. These kinds of models are based on a strong assumption that the effect across the panel is homogeneous. With the estimation of the random and fixed 
effect panel models, some specification issues are expected, the first and foremost of which is the endogeneity issue of Greenfield investment. A wide variety of techniques and different variables have been adopted to mitigate the endogeneity issue of foreign direct investment. Lagged value of Greenfield will be used as an instrument for Greenfield to deal with the problem (Alfaro et al., 2004). The main reason is that foreign direct investment is expected to reinforce itself from time to time (Wheeler \& Mody, 1992). Therefore, the endogeneity issue would be best dealt with by the dynamic panel model that includes lagged value of FDI as an instrumental variable. The GMM estimated method will be used on data for the total entrepreneurial activity and the opportunity- and necessity-based components.

This paper uses a dynamic panel data model and generalized method of moments (GMM) estimation method to model the impact of Greenfield investment on domestic entrepreneurship. The dynamic panel data model and GMM estimation deal with the potential FDI endogeneity problem.

The following dynamic panel data models are estimated to model the impact of Greenfield on domestic entrepreneurship.

$$
Y_{i, t}=\beta_{0}+\beta_{1} Y_{i, t-1}+\beta_{2} \text { lngreen }_{, t}+\beta_{3} X_{i, t}+e_{i, t}
$$

where $Y_{i, t}$ is the total entrepreneurial activity, $Y_{i t-1}$ is the lagged value of the total entrepreneurial activity. $\operatorname{lngreen}_{i, t}$ is the total of net Greenfield investments inflow to the host country in natural $\log$ form. $\mathrm{X}_{\mathrm{i}, \mathrm{t}}$ represents the control variables for the determinants of total entrepreneurial activity including gross domestic product growth rate, entrepreneurial intentions, and the fear of failure rates, and $\mathrm{e}_{\mathrm{i}, \mathrm{t}}$ is the random error term. Adopting from existing similar studies (for example Albulescu and Tămăşilă 2013), we used fear of failure rates, GDP growth rate, and entrepreneurial intentions as explanatory variables for the equations.

\section{Economic context}

It is important to determine how economic context influences the EntrepreneurshipGreenfield nexus across countries. Situations of weak growth, stagnation, and crisis are associated with unemployment as people who are forced to look for alternative sources of income become necessity entrepreneurs (Peris-Ortiz et al., 2012; Klapper \& Love, 2011). At the same time, growth periods are favorable to the discovery of opportunities and innovation and thus higher rate of opportunity entrepreneurs (Klapper \& Love, 2011).

The 2008-2009 financial crisis witnessed a sharp decline in both the rate of FDI outflows and inflows or the domestic entrepreneurship. Kim and Seo (2003) find that the impact of FDI on domestic entrepreneurship appears to be less significant in the sample that includes the post-crisis period. The finding suggests that a positive shock to domestic investment in the period of high growth could be interpreted as an alarming message for foreign investors. Alternatively, an exogeneous decline in domestic investment in the period of low growth is associated with a rise in the inflow of foreign direct investment.

\section{Empirical results and discussion}

We have conducted one main overall test and three sets of robustness checks. The main test is conducted over the entire sample in 2001-2018 (panel A). The other sets 
of analysis consist of similar methodology over the same number of panels, but the sample period has been split into pre-crisis (panel B), during crisis (panel C), and postcrisis (panel D). For each set of tests, both fixed-effect and random-effect models have been shown along with the Hausman test (to determine whether the fixed-effect or random-effect is more preferred). In addition to the panel on total entrepreneurial activity, we have also made distinction between necessity-driven entrepreneurship and opportunity-driven entrepreneurship.

Table 1 above presents descriptive statistics for all the variables. The summary indicates a great deal of variations within each variable with GDP growth rate (gdpgrowth) ranging from -62 to $123 \%$ while its average only at $4 \%$. The same is also true for Greenfield investment so we take log of this variable (lngreen). Fear of failure rate (fof) represents the percentage of population who indicates that fear of failure leads them not to open a business while entrepreneurial intentions (ei) refers the percentage of population who intend to open a new venture and this figure varies significantly from 0 to $90 \%$. As predicted, the sum of opportunity-based entrepreneurship (opportunity) and necessity-based entrepreneurship (necessity) are equal to total entrepreneurship (tea) in every single statistic, which is actually observed in Table 1.

Table 2 correlation matrix shows no indication of multicollinearity and there is no significant correlation between lngreen and tea. However, the correlation between tea and $e i$ is strong and statistically negative.

Table 3 shows the results of panel A, which is the main model of our paper. As can be seen in the table, Greenfield investment exerts negative influence on the total entrepreneurial activity with the coefficients lngreen being negative in all settings except for the random-effect model on necessity entrepreneurship. Another noteworthy feature is that the Ingreen coefficient shows lesser degree in terms of both magnitude and statistical significance in models (7), (8), and (9) that measure the impact of Greenfield on necessity entrepreneurship. Correspondingly, the inflows of Greenfield investment would have damaging impact on the rate of opportunity-based entrepreneurs while not necessarily decreasing the rate of necessity-based entrepreneurs. This is referred to as the crowding-out effect of FDI. The crowding-out effect of Greenfield could be explained by the replacement of entrepreneurship by employment. More specifically, setting up a new Greenfield venture in the foreign country may involve employing potential entrepreneurs, contributing to a reduction in the rate of potential future entrepreneurs (Goel, 2018). Along with another related dimension, foreign investors might also lure some potential entrepreneurs as employees. This would result in a reduction in domestic entrepreneurship (as employment replaces entrepreneurship). The overall impact of FDI on entrepreneurship might then be negative or positive and

Table 2 Correlation matrix

\begin{tabular}{lllllll}
\hline & Gdpgrowth & Fof & Ei & Tea & Lngreen & Gdpcapita \\
\hline Gdpgrowth & 1.00 & & & & & \\
Fof & -0.10 & 1.0 & & & & \\
Ei & 0.25 & -0.27 & 1.00 & & & \\
Tea & 0.24 & -0.31 & 0.82 & 1.00 & & \\
Lngreen & -0.13 & 0.26 & -0.52 & -0.45 & 1.00 & 1.00 \\
Gdpcapita & -0.33 & 0.17 & -0.65 & -0.56 & 0.57 & \\
\hline
\end{tabular}


Table 3 Impact of Greenfield investment on necessity driven, opportunity-driven, and total entrepreneurial activity

\begin{tabular}{|c|c|c|c|c|c|c|c|c|c|}
\hline & \multicolumn{3}{|l|}{ Tea } & \multicolumn{3}{|c|}{ Opportunity } & \multicolumn{3}{|l|}{ Necessity } \\
\hline & $\begin{array}{l}\text { (1) } \\
\text { Random }\end{array}$ & $\begin{array}{l}\text { (2) } \\
\text { Fixed }\end{array}$ & $\begin{array}{l}\text { (3) } \\
\text { GMM }\end{array}$ & $\begin{array}{l}\text { (4) } \\
\text { Random }\end{array}$ & $\begin{array}{l}\text { (5) } \\
\text { Fixed }\end{array}$ & $\begin{array}{l}\text { (6) } \\
\text { GMM }\end{array}$ & $\begin{array}{l}\text { (7) } \\
\text { Random }\end{array}$ & $\begin{array}{l}\text { (8) } \\
\text { Fixed }\end{array}$ & $\begin{array}{l}\text { (9) } \\
\text { GMM }\end{array}$ \\
\hline$T e a_{t-1}$ & & & $\begin{array}{l}0.2^{* * *} \\
(0.03)\end{array}$ & & & & & & \\
\hline Opportunity $_{t-1}$ & & & & & & $\begin{array}{l}0.2^{* * *} \\
(0.03)\end{array}$ & & & \\
\hline Necessity $_{t-1}$ & & & & & & & & & $\begin{array}{l}0.31^{* * *} \\
(0.03)\end{array}$ \\
\hline Lngreen & $\begin{array}{l}-0.37^{* * *} \\
(0.11)\end{array}$ & $\begin{array}{l}-0.50^{* * *} \\
(0.13)\end{array}$ & $\begin{array}{l}-0.26^{* * *} \\
(0.09)\end{array}$ & $\begin{array}{l}-0.19^{* *} \\
(0.1)\end{array}$ & $\begin{array}{l}-0.22^{*} \\
(0.12)\end{array}$ & $\begin{array}{l}-0.03 \\
(0.08)\end{array}$ & $\begin{array}{l}-0.07 \\
(0.05)\end{array}$ & $\begin{array}{l}-0.14^{* *} \\
(0.06)\end{array}$ & $\begin{array}{l}-0.04 \\
(0.04)\end{array}$ \\
\hline Gdpcapita & $\begin{array}{l}-0.28 \\
(0.32)\end{array}$ & $\begin{array}{l}1.62^{* * *} \\
(0.51)\end{array}$ & $\begin{array}{l}-1.54 \\
(2.53)\end{array}$ & $\begin{array}{l}0.30 \\
(0.26)\end{array}$ & $\begin{array}{l}2.16^{* * *} \\
(0.42)\end{array}$ & $\begin{array}{l}-0.66 \\
(1.97)\end{array}$ & $\begin{array}{l}-0.80^{* * *} \\
(0.1)\end{array}$ & $\begin{array}{l}-0.48^{* *} \\
(0.22)\end{array}$ & $\begin{array}{l}-1.7^{*} \\
(0.001)\end{array}$ \\
\hline Gdpgrowth & $\begin{array}{l}-0.04 \\
(0.04)\end{array}$ & $\begin{array}{l}-0.05 \\
(0.04)\end{array}$ & $\begin{array}{l}0.002^{* * *} \\
(0.004)\end{array}$ & $\begin{array}{l}-0.004 \\
(0.03)\end{array}$ & $\begin{array}{l}-0.01 \\
(0.03)\end{array}$ & $\begin{array}{l}0.001^{* * *} \\
(0.004)\end{array}$ & $\begin{array}{l}-0.03^{*} \\
(0.02)\end{array}$ & $\begin{array}{l}-0.04^{* *} \\
(0.02)\end{array}$ & $\begin{array}{l}0.005^{* *} \\
(0.002)\end{array}$ \\
\hline Fof & $\begin{array}{l}-0.04^{* *} \\
(0.02)\end{array}$ & $\begin{array}{l}-0.03^{*} \\
(0.02)\end{array}$ & $\begin{array}{l}-0.07^{* * *} \\
(0.02)\end{array}$ & $\begin{array}{l}-0.04^{* *} \\
(0.02)\end{array}$ & $\begin{array}{l}-0.03^{*} \\
(0.02)\end{array}$ & $\begin{array}{l}-0.05^{* * *} \\
(0.01)\end{array}$ & $\begin{array}{l}-0.02^{* * *} \\
(0.007)\end{array}$ & $\begin{array}{l}-0.01 \\
(0.008)\end{array}$ & $\begin{array}{l}-0.01^{*} \\
(0.007)\end{array}$ \\
\hline Ei & $\begin{array}{l}0.30^{* * *} \\
(0.02)\end{array}$ & $\begin{array}{l}0.22^{* * *} \\
(0.02)\end{array}$ & $\begin{array}{l}0.3^{* * *} \\
(0.02)\end{array}$ & $\begin{array}{l}0.19^{* * *} \\
(0.02)\end{array}$ & $\begin{array}{l}0.14^{* * *} \\
(0.02)\end{array}$ & $\begin{array}{l}0.2^{* * *} \\
(0.02)\end{array}$ & $\begin{array}{l}0.09^{* * *} \\
(0.007)\end{array}$ & $\begin{array}{l}0.05^{* * *} \\
(0.008)\end{array}$ & $\begin{array}{l}0.08^{* * *} \\
(0.008)\end{array}$ \\
\hline Constant & $\begin{array}{l}12.94^{* * *} \\
(3.01)\end{array}$ & $\begin{array}{l}-3.56 \\
(4.85)\end{array}$ & $\begin{array}{l}14.09 \\
(10.8)\end{array}$ & $\begin{array}{l}4.52^{*} \\
(2.45)\end{array}$ & $\begin{array}{l}-12.8^{* * *} \\
(4.0)\end{array}$ & $\begin{array}{l}7.02 \\
(8.39)\end{array}$ & $\begin{array}{l}10.09^{* * *} \\
(1.15)\end{array}$ & $\begin{array}{l}7.92^{* * *} \\
(2.04)\end{array}$ & $\begin{array}{l}8.28^{*} \\
(4.31)\end{array}$ \\
\hline Observations & 695 & 695 & 571 & 555 & 555 & 447 & 555 & 555 & 447 \\
\hline R-squared & 0.53 & 0.24 & & 0.44 & 0.18 & & 0.55 & 0.11 & \\
\hline Adjusted $\mathrm{R}^{2}$ & 0.52 & 0.12 & & 0.44 & 0.03 & & 0.54 & 0.05 & \\
\hline F statistic & $767.22^{* * *}$ & $\begin{array}{l}37.57^{* * *} \\
(\mathrm{df}=5 ; \\
604)\end{array}$ & $\begin{array}{l}163.55 \\
(d f=6, \\
564)\end{array}$ & $438.01^{* * *}$ & $\begin{array}{l}21.04^{* * *} \\
(\mathrm{df}=5 \\
466)\end{array}$ & $\begin{array}{l}105.22 \\
(\mathrm{df}=6, \\
440)\end{array}$ & $661.76^{* * *}$ & $\begin{array}{l}11.84^{* * *} \\
(\mathrm{df}=5 \\
466)\end{array}$ & $\begin{array}{l}129.72 \\
(\mathrm{df}=6, \\
440)\end{array}$ \\
\hline
\end{tabular}

Note: ${ }^{*} p<0.1 ;{ }^{* *} p<0.05 ;{ }^{* * *} p<0.01$

might vary across demographic groups. For example, female entrepreneurs might face special challenges in competing against foreign investors (Goel, 2018). In addition, Ashraf et al. (2016) and Calderón et al., (2002) both state that Greenfield investment bears crowding-out effect and hamper long-term economic growth. Since productive entrepreneurship is positively related to economic growth (Salgado-Banda, 2007), Greenfield investment would damage the long-term economic potential, which in turn decrease the rate of opportunity entrepreneurs.

Another interesting result is that high GDP growth rate and high GDP per capita are negatively associated with necessity-driven entrepreneurs while we find no significant evidence of the relationship between GDP growth rate or GDP per capita and opportunity entrepreneurship. These results are consistent with the current literature. Necessity-driven entrepreneurs often have poor education, run smaller businesses, and their firms tend to lag behind others (Poschke, 2012). As soon as necessity-based entrepreneurs find better opportunities elsewhere, they will abandon their businesses (Rissman, 2003). When people have higher standard of living and sufficient livelihood, they will be less motivated to pursue entrepreneurship out of necessity (Poschke, 2012). Secondly, the direction and significance of the coefficients $f o f$ and $e i$ are generally consistent across all models. More specifically, fear of failure (fof) would prevent entrepreneurs from setting up new ventures out of both opportunity and necessity. Next, entrepreneurial intention is the conscious state of mind that precedes 
entrepreneurial actions and positively direct people toward entrepreneurial behaviors (Moriano, Gorgievski, Laguna, Stephan, \& Zarafshani, 2012).

Similar findings have also been found in the pre-crisis period as can be seen in Table 4 . The inflows of Greenfield investment significantly lower the rate of total entrepreneurship and opportunity-driven entrepreneurship. The distinct finding is that Greenfield may actually increase necessity-driven entrepreneurs with coefficient lngreen being significantly positive in model 8 . This could be explained by the fact that the entry of Greenfield venture might drive up competition pressure for domestic firms, forcing them out of market and thereby decreasing employment in host economy (Karlsson, Lundin, Sjoholm, \& He, 2007). Giant MNEs may raise the average wages in the local narrowly-defined industry and then qualify job growth in the host countries. Subsequently, there would be a higher number of potential entrepreneurs who start up new business upon losing their jobs.

Regarding entrepreneurship during turbulent times, we see no significant relationship between entrepreneurship and Greenfield investment during crisis in Table 5. Entrepreneurial activity is also unrelated to fear of failure and entrepreneurial intentions. Meanwhile, the other coefficients such as GDP per capita and GDP growth rate show contradictory results in between fixed-effect and random-effect model. We are unable to carry out GMM estimation method in the crisis period due to insufficient observations. Thus, we cannot generalize the results regarding the impact of Greenfield investment during the turbulent times. Future research could resolve data issue by conducting studies at the country level to examine the distinct impact Greenfield investment may have on different country settings.

Table 4 Relationship between Greenfield investment and entrepreneurship in pre-crisis period

\begin{tabular}{|c|c|c|c|c|c|c|c|c|c|}
\hline & \multicolumn{3}{|l|}{ Tea } & \multicolumn{3}{|c|}{ Opportunity } & \multicolumn{3}{|l|}{ Necessity } \\
\hline & $\begin{array}{l}\text { (1) } \\
\text { Random }\end{array}$ & $\begin{array}{l}(2) \\
\text { Fixed }\end{array}$ & $\begin{array}{l}\text { (3) } \\
\text { GMM }\end{array}$ & $\begin{array}{l}\text { (4) } \\
\text { Random }\end{array}$ & $\begin{array}{l}(5) \\
\text { Fixed }\end{array}$ & $\begin{array}{l}\text { (6) } \\
\text { GMM }\end{array}$ & $\begin{array}{l}\text { (7) } \\
\text { Random }\end{array}$ & $\begin{array}{l}(8) \\
\text { Fixed }\end{array}$ & $\begin{array}{l}\text { (9) } \\
\text { GMM }\end{array}$ \\
\hline$T e a_{t-1}$ & & & $\begin{array}{l}0.41^{* * *} \\
(0.07)\end{array}$ & & & & & & \\
\hline Opportunity $_{t-1}$ & & & & & & $\begin{array}{l}0.53^{* * *} \\
(0.09)\end{array}$ & & & \\
\hline Necessity $_{t-1}$ & & & & & & & & & $\begin{array}{l}0.51^{* * *} \\
(0.08)\end{array}$ \\
\hline Lngreen & $\begin{array}{l}-0.38^{* *} \\
(0.18)\end{array}$ & $\begin{array}{l}-0.12 \\
(0.20)\end{array}$ & $\begin{array}{l}-0.24^{* *} \\
(0.12)\end{array}$ & $\begin{array}{l}-0.35^{* *} \\
(0.14)\end{array}$ & $\begin{array}{l}-0.18 \\
(0.15)\end{array}$ & $\begin{array}{l}-0.22^{*} \\
(0.13)\end{array}$ & $\begin{array}{l}0.002 \\
(0.07)\end{array}$ & $\begin{array}{l}0.14^{*} \\
(0.08)\end{array}$ & $\begin{array}{l}-0.02 \\
(0.09)\end{array}$ \\
\hline Gdpcapita & $\begin{array}{l}-0.76 \\
(0.60)\end{array}$ & $\begin{array}{l}-1.45 \\
(1.27)\end{array}$ & $\begin{array}{l}-0.02 \\
(0.1)\end{array}$ & $\begin{array}{l}-0.11 \\
(0.48)\end{array}$ & $\begin{array}{l}0.18 \\
(0.95)\end{array}$ & $\begin{array}{l}0.04 \\
(0.08)\end{array}$ & $\begin{array}{l}-0.57^{* * *} \\
(0.20)\end{array}$ & $\begin{array}{l}-1.20^{* *} \\
(0.51)\end{array}$ & $\begin{array}{l}0.06^{*} \\
(0.04)\end{array}$ \\
\hline Gdpgrowth & $\begin{array}{l}0.15 \\
(0.12)\end{array}$ & $\begin{array}{l}0.18 \\
(0.14)\end{array}$ & $\begin{array}{l}-0.00^{* *} \\
(0.00)\end{array}$ & $\begin{array}{l}0.13 \\
(0.09)\end{array}$ & $\begin{array}{l}0.10 \\
(0.11)\end{array}$ & $\begin{array}{l}0.014^{*} \\
(0.08)\end{array}$ & $\begin{array}{l}0.01 \\
(0.05)\end{array}$ & $\begin{array}{l}0.07 \\
(0.06)\end{array}$ & $\begin{array}{l}0.01^{*} \\
(0.11)\end{array}$ \\
\hline Fof & $\begin{array}{l}-0.0003 \\
(0.04)\end{array}$ & $\begin{array}{l}0.01 \\
(0.04)\end{array}$ & $\begin{array}{l}-0.09^{* * * *} \\
(0.03)\end{array}$ & $\begin{array}{l}-0.02 \\
(0.03)\end{array}$ & $\begin{array}{l}-0.01 \\
(0.03)\end{array}$ & $0.07 * * *(0.02)$ & $\begin{array}{l}0.01 \\
(0.01)\end{array}$ & $\begin{array}{l}0.02 \\
(0.02)\end{array}$ & $\begin{array}{l}-0.005 \\
(0.675)\end{array}$ \\
\hline Ei & $\begin{array}{l}0.26^{* * *} \\
(0.04)\end{array}$ & $\begin{array}{l}0.16^{* * *} \\
(0.05)\end{array}$ & $\begin{array}{l}0.24^{* * *} \\
(0.04)\end{array}$ & $\begin{array}{l}0.14^{* * * *} \\
(0.03)\end{array}$ & $\begin{array}{l}0.09^{* *} \\
(0.04)\end{array}$ & $\begin{array}{l}0.12^{* * * *} \\
(0.03)\end{array}$ & $\begin{array}{l}0.11^{* * *} \\
(0.02)\end{array}$ & $\begin{array}{l}0.06^{* * *} \\
(0.02)\end{array}$ & $\begin{array}{l}0.06^{* * *} \\
(0.02)\end{array}$ \\
\hline Constant & $\begin{array}{l}15.25^{* *} \\
(6.14)\end{array}$ & & $\begin{array}{l}6.91^{* * *} \\
(1.39)\end{array}$ & $\begin{array}{l}8.55^{*} \\
(4.89)\end{array}$ & & $\begin{array}{l}5.53^{* * *} \\
(1.43)\end{array}$ & $\begin{array}{l}5.52^{* *} \\
(2.15)\end{array}$ & & $\begin{array}{l}-4.2^{*} \\
(2.43)\end{array}$ \\
\hline R-squared & 0.53 & 0.18 & & 0.39 & 0.09 & & 0.61 & 0.4 & \\
\hline F statistic & $141.77^{* * *}$ & $3.56^{* * *}$ & $\begin{array}{l}60.14 \\
(d f=6 \\
75)\end{array}$ & $78.04^{* * *}$ & 1.65 & $\begin{array}{l}27.66 \\
(d f=6,74)\end{array}$ & $195.85^{* * *}$ & & $\begin{array}{l}84.62 \\
(\mathrm{df}=6, \\
74)\end{array}$ \\
\hline Observations & 82 & 82 & 82 & 82 & 82 & 82 & 82 & 82 & 82 \\
\hline
\end{tabular}

Note: ${ }^{*} \mathrm{p}<0.1 ;{ }^{* *} \mathrm{p}<0.05 ;{ }^{* * *} \mathrm{p}<0.01$ 
Table 5 Relationship between Greenfield investment and entrepreneurship during crisis

\begin{tabular}{|c|c|c|c|c|c|c|}
\hline & \multicolumn{2}{|l|}{ Tea } & \multicolumn{2}{|c|}{ Opportunity } & \multicolumn{2}{|l|}{ Necessity } \\
\hline & $\begin{array}{l}1) \\
\text { Random }\end{array}$ & $\begin{array}{l}(2) \\
\text { Fixed }\end{array}$ & $\begin{array}{l}\text { (4) } \\
\text { Random }\end{array}$ & $\begin{array}{l}(5) \\
\text { Fixed }\end{array}$ & $\begin{array}{l}7) \\
\text { Random }\end{array}$ & $\begin{array}{l}(8) \\
\text { Fixed }\end{array}$ \\
\hline Lngreen & $\begin{array}{l}-0.03 \\
(0.22)\end{array}$ & $\begin{array}{l}0.14 \\
(0.23)\end{array}$ & $\begin{array}{l}0.07 \\
(0.16)\end{array}$ & $\begin{array}{l}0.24 \\
(0.18)\end{array}$ & $\begin{array}{l}-0.06 \\
(0.10)\end{array}$ & $\begin{array}{l}0.02 \\
(0.13)\end{array}$ \\
\hline Gdpcapita & $\begin{array}{l}-2.50^{* * *} \\
(0.85)\end{array}$ & $\begin{array}{l}5.80^{* *} \\
(2.46)\end{array}$ & $\begin{array}{l}-1.10^{*} \\
(0.62)\end{array}$ & $\begin{array}{l}5.27^{* * *} \\
(1.86)\end{array}$ & $\begin{array}{l}-1.07^{* * *} \\
(0.33)\end{array}$ & $\begin{array}{l}0.80 \\
(1.42)\end{array}$ \\
\hline Gdpgrowth & $\begin{array}{l}-0.15^{* *} \\
(0.07)\end{array}$ & $\begin{array}{l}-0.02 \\
(0.07)\end{array}$ & $\begin{array}{l}-0.11^{* *} \\
(0.05)\end{array}$ & $\begin{array}{l}-0.01 \\
(0.05)\end{array}$ & $\begin{array}{l}-0.06 \\
(0.04)\end{array}$ & $\begin{array}{l}-0.04 \\
(0.04)\end{array}$ \\
\hline Fof & $\begin{array}{l}-0.002 \\
(0.04)\end{array}$ & $\begin{array}{l}-0.08^{*} \\
(0.04)\end{array}$ & $\begin{array}{l}0.01 \\
(0.03)\end{array}$ & $\begin{array}{l}-0.05 \\
(0.03)\end{array}$ & $\begin{array}{l}-0.01 \\
(0.02)\end{array}$ & $\begin{array}{l}-0.03 \\
(0.02)\end{array}$ \\
\hline$E i$ & $\begin{array}{l}0.10^{*} \\
(0.06)\end{array}$ & $\begin{array}{l}-0.09 \\
(0.06)\end{array}$ & $\begin{array}{l}0.07^{*} \\
(0.04)\end{array}$ & $\begin{array}{l}-0.06 \\
(0.05)\end{array}$ & $\begin{array}{l}0.06^{* *} \\
(0.02)\end{array}$ & $\begin{array}{l}-0.05 \\
(0.04)\end{array}$ \\
\hline Constant & $\begin{array}{l}33.36^{* * *} \\
(8.41)\end{array}$ & & $\begin{array}{l}15.75^{* *} \\
(6.16)\end{array}$ & & $\begin{array}{l}13.15^{* * *} \\
(3.41)\end{array}$ & \\
\hline R-squared & 0.39 & 0.37 & 0.27 & 0.44 & 0.50 & 0.24 \\
\hline F statistic & $41.86^{* * *}$ & $2.78^{* *}$ & $23.45^{* * *}$ & $3.76^{* *}$ & $63.97^{* * *}$ & 1.51 \\
\hline Observations & 73 & 73 & 71 & 71 & 71 & 71 \\
\hline
\end{tabular}

Note: ${ }^{*} \mathrm{p}<0.1 ;{ }^{* *} \mathrm{p}<0.05 ;{ }^{* * *} \mathrm{p}<0.01$

Finally, the results in post-crisis time are generally in line with the findings from our main model as Greenfield investment illustrates a negative impact on total entrepreneurial activity (Table 6). However, Greenfield appears to no longer adversely influence the rate of opportunity-based entrepreneurship. This empirical finding may suggest that, after crisis, policy makers have re-considered the strategies to attract FDI and offset the unfavorable effect of Greenfield investment (Danakol et al., 2016). Major developed countries have taken a big hit from FDI response during the crisis period and policy makers have since shown enhanced focus on "sustainable FDI" (Poulsen \& Hufbauer, 2011).

\section{Conclusion}

Our paper is the first one to examine and disentangle the impact of Greenfield investment on entrepreneurship as previous research points to contradictory results when referring to the FDI-entrepreneurship nexus. The results show that Greenfield investment negatively affects the level of entrepreneurial activity in the host countries and the results are robust across different settings. Our paper generates important theoretical and practical implications. Previous studies showed inconsistent findings toward the impact of FDI on entrepreneurship. This paper provides another explanation that Greenfield and M\&A are separate categories of foreign investment and thus pooling those two could thwart the validity of the prediction results. Additionally, policy makers could devise more feasible and hands-on strategies in evaluating and attracting different types of FDI projects.

However, there are several caveats that should be taken when generalizing the results from our paper. First, the influence of Greenfield on entrepreneurship has been insignificant during crisis and the negative impact is less significant on necessity entrepreneurship than on opportunity-based entrepreneurship. That could not only be due to data limitation but also suggests the involvement of other important mediators and moderators. Future research could take into consideration the effect of institution 
Table 6 Relationship between Greenfield investment and entrepreneurship after-crisis period

\begin{tabular}{|c|c|c|c|c|c|c|c|c|c|}
\hline & Tea & & & Opportur & & & Necessity & & \\
\hline & $\begin{array}{l}\text { (1) } \\
\text { Random }\end{array}$ & $\begin{array}{l}\text { (2) } \\
\text { Fixed }\end{array}$ & $\begin{array}{l}\text { (3) } \\
\text { GMM }\end{array}$ & $\begin{array}{l}\text { (4) } \\
\text { Random }\end{array}$ & $\begin{array}{l}\text { (5) } \\
\text { Fixed }\end{array}$ & $\begin{array}{l}\text { (6) } \\
\text { GMM }\end{array}$ & $\begin{array}{l}\text { (7) } \\
\text { Random }\end{array}$ & $\begin{array}{l}\text { (8) } \\
\text { Fixed }\end{array}$ & $\begin{array}{l}\text { (9) } \\
\text { GMM }\end{array}$ \\
\hline$T e a_{t-1}$ & & & $\begin{array}{l}-0.42^{* * *} \\
(0.08)\end{array}$ & & & & & & \\
\hline Opportunity $_{t-1}$ & & & & & & $\begin{array}{l}-0.39^{* * *} \\
(0.1)\end{array}$ & & & \\
\hline Necessity $_{t-1}$ & & & & & & & & & $\begin{array}{l}0.47^{* * *} \\
(0.12)\end{array}$ \\
\hline Lngreen & $\begin{array}{l}-0.24^{*} \\
(0.13)\end{array}$ & $\begin{array}{l}-0.53^{* * *} \\
(0.16)\end{array}$ & $\begin{array}{l}-0.42^{* *} \\
(0.12)\end{array}$ & $\begin{array}{l}-0.06 \\
(0.12)\end{array}$ & $\begin{array}{l}-0.21 \\
(0.16)\end{array}$ & $\begin{array}{l}-0.24 \\
(0.28)\end{array}$ & $\begin{array}{l}-0.02 \\
(0.06)\end{array}$ & $\begin{array}{l}-0.20^{* *} \\
(0.08)\end{array}$ & $\begin{array}{l}-0.12 \\
(0.14)\end{array}$ \\
\hline Gdpcapita & $\begin{array}{l}-0.93^{* * *} \\
(0.35)\end{array}$ & $\begin{array}{l}0.30 \\
(1.10)\end{array}$ & $\begin{array}{l}-0.15^{* *} \\
(0.07)\end{array}$ & $\begin{array}{l}-0.33 \\
(0.29)\end{array}$ & $\begin{array}{l}2.53^{* *} \\
(1.12)\end{array}$ & $\begin{array}{l}-0.06 \\
(0.08)\end{array}$ & $\begin{array}{l}-0.94^{* * *} \\
(0.14)\end{array}$ & $\begin{array}{l}-2.17^{* * *} \\
(0.57)\end{array}$ & $\begin{array}{l}-0.06 \\
(0.04)\end{array}$ \\
\hline Gdpgrowth & $\begin{array}{l}0.01 \\
(0.05)\end{array}$ & $\begin{array}{l}-0.03 \\
(0.05)\end{array}$ & $\begin{array}{l}0.34^{* * *} \\
(0.18)\end{array}$ & $\begin{array}{l}0.05 \\
(0.04)\end{array}$ & $\begin{array}{l}0.01 \\
(0.04)\end{array}$ & $\begin{array}{l}0.06^{* * *} \\
(0.09)\end{array}$ & $\begin{array}{l}-0.02 \\
(0.02)\end{array}$ & $\begin{array}{l}-0.01 \\
(0.02)\end{array}$ & $\begin{array}{l}-0.37^{* * *} \\
(0.1)\end{array}$ \\
\hline Fof & $\begin{array}{l}-0.07^{* * *} \\
(0.02)\end{array}$ & $\begin{array}{l}-0.05^{* *} \\
(0.02)\end{array}$ & $\begin{array}{l}0.11^{* * *} \\
(0.05)\end{array}$ & $\begin{array}{l}-0.06^{* * *} \\
(0.02)\end{array}$ & $\begin{array}{l}-0.02 \\
(0.02)\end{array}$ & $\begin{array}{l}0.14^{* * *} \\
(0.04)\end{array}$ & $\begin{array}{l}-0.03^{* * *} \\
(0.01)\end{array}$ & $\begin{array}{l}-0.02 \\
(0.01)\end{array}$ & $\begin{array}{l}0.04^{* *} \\
(0.02)\end{array}$ \\
\hline Ei & $\begin{array}{l}0.28^{* * *} \\
(0.02)\end{array}$ & $\begin{array}{l}0.21^{* * *} \\
(0.02)\end{array}$ & $\begin{array}{l}0.18^{* * *} \\
(0.05)\end{array}$ & $\begin{array}{l}0.18^{* * *} \\
(0.02)\end{array}$ & $\begin{array}{l}0.10^{* * *} \\
(0.02)\end{array}$ & $\begin{array}{l}0.06 \\
(0.05)\end{array}$ & $\begin{array}{l}0.09^{* * *} \\
(0.01)\end{array}$ & $\begin{array}{l}0.05^{* * * *} \\
(0.01)\end{array}$ & $\begin{array}{l}0.03 \\
(0.03)\end{array}$ \\
\hline Constant & $\begin{array}{l}19.36^{* * *} \\
(3.37)\end{array}$ & & $\begin{array}{l}7.82^{* * *} \\
(1.89)\end{array}$ & $\begin{array}{l}10.24^{* * *} \\
(2.82)\end{array}$ & & $\begin{array}{l}5.71^{* * *} \\
(2.22)\end{array}$ & $\begin{array}{l}11.59^{* * *} \\
(1.33)\end{array}$ & & $\begin{array}{l}9.14^{* * *} \\
(3.11)\end{array}$ \\
\hline R-squared & 0.54 & 0.21 & & 0.47 & 0.12 & & 0.57 & 0.12 & \\
\hline F statistic & $576.76^{* * *}$ & $21.11^{* * *}$ & & $308.91^{* * *}$ & $7.12^{* * *}$ & & $452.06^{* * *}$ & $7.50^{* * *}$ & \\
\hline Observations & 491 & 491 & 373 & 354 & 354 & 253 & 354 & 354 & 253 \\
\hline
\end{tabular}

Note: ${ }^{*} \mathrm{p}<0.1 ;{ }^{* *} \mathrm{p}<0.05 ;{ }^{* * *} \mathrm{p}<0.01$

quality and regulations, which have been proved to exert influence on both Greenfield and entrepreneurial activity. Second, it should be carried out similar work to another category of FDI, which is mergers and acquisitions, so that comparison could be made between M\&A and Greenfield investment.

Abbreviations

Greenfield: Greenfield investment; M\&A: Mergers and acquisitions; GDP: Gross domestic investment; FDI: Foreign direct investment

\section{Acknowledgements}

Not applicable

\section{Authors' contributions}

TSH provided the concept and the design of the research. VTC provided the analysis and interpretation of data, contributed in drafting the article, and revised it critically for important intellectual content and final approval of the version to be submitted. ANTN supplied the design of the study, contributed in the acquisition of the data, and drafted the manuscript. DHTN supplied the analysis and interpretation. MTTN provided the revised article critically for important intellectual content and gave approval of the version to be submitted. The authors read and approved the final manuscript.

Funding

This research including the design of the study, the collection of data and the writing of the manuscript is funded by National Economics University, Hanoi, Vietnam. The contents of this publication are solely the responsibility of the authors.

Availability of data and materials

Our data is at the macro level and all available in either GEM or UNCTAD. Please note that do-files are also available upon request.

\section{Declarations}

Competing interests

The authors declare that they have no competing interests. 
Received: 7 January 2021 Accepted: 1 June 2021

Published online: 10 July 2021

\section{References}

Alfaro, Laura, and Andrés Rodríguez-Clare, 2004, "Multinationals and Linkages: An Empirical Investigation," Economía,\&nbsp; 4(2), 113-170.

Aghion, P., \& Howitt, P. (1992). A model of growth through creative destruction. Econometrica, 60(2), 323-351. https://doi. org $/ 10.2307 / 2951599$

Audretsch, D. B., and Acs, Z. J. (1994). New-firm startups, technology, and macroeconomic fluctuations. Small Business Economics, 6, 439-449

Albulescum, C. T., \& Tămăşilă, M. (2014). The impact of FDI on entrepreneurship in the European countries. Social and Behavioral Sciences, 124(2), 219-228.

Ashraf, A., and Herzer, D. (2014). The effect of Greenfield investment and M\&As on domestic investment in developing countries. Applied Economic Letters, 21(14), 997-1000.

Ahmeti, F., \& Kukaj, H. (2016). The importance of foreign direct investments on economic development in transitional countries: A case study of Kosovo. European Scientific Journal, 12(7), 99-108.

Aitken, B. J., \& Harrison, A. E. (1999). Do domestic firms benefit from direct foreign investment? Evidence from Venezuela. American Economic Review, 89(3), 605-618. https://doi.org/10.1257/aer.89.3.605.

Allison,\&nbsp;P.D.\&nbsp; Waterman R. (2002). Fixed effects negative binomial regression models R. Stolzenberg (Ed.), Sociological Methodology, Basil Blackwell, Boston.

Alon, I., Elia, S., \& Li, S. (2020). Greenfield or M\&A? An institutional and learning perspective on the establishment mode choice of Chinese outward investments. Journal of International Management, 26(3), 100758. https:/doi.org/10.1016/j.intman.2020.100758.

Amoroso, S., and Müller, B. (2018). The short-run effects of knowledge intensive greenfield FDI on new domestic entry. The Journal of Technology Transfer, 43(3), 815-836.

Apostolov, M. (2017). The impact of FDI on the performance and entrepreneurship of domestic firms. Journal of International Entrepreneurship, 15(4), 319-415.

Ashraf, A., Herzer, D., \& Nunnenkamp, P. (2016). The effects of Greenfield FDI and cross-border M\&As on total factor productivity. The World Economy, 39(11), 1728-1755. https://doi.org/10.1111/twec.12321.

Ayyagari, M., \& Kosová, A. (2010). Does FDI facilitate domestic entry? Evidence from the Czech Republic. Review of International Economics, 18(1), 14-29. https://doi.org/10.1111/j.1467-9396.2009.00854.x.

Balsvik, R., and Haller, S. (2011). Foreign Firms and Host-country Productivity: Does the Mode of Entry Matter?. Oxford Economic Papers, 63(1), 158-186.

Brock, W. A., \& Evans, D. S. (1989). Small business economics. Small Business Economics, 1(1), 7-20. https://doi.org/10.1007/BF00389913.

Blonigen, B. A., and Piger, J. (2011). Determinants of foreign direct investment NBER Working Paper, 16704.

Calderon, C., Loayza, N., and Serven, L. (2002). Greenfield FDI vs. mergers and acquisitions: Does the distinction matter? Central Bank of Chile, Working Papers No. 173

Crumpton, M. A. (2012). Innovation and entrepreneurship. The Bottom Line: Managing Library Finances, 25(3), 98-101. https:// doi.org/10.1108/08880451211276539.

Danakol, S.H., Estrin, S., Reynolds, P., and Weitzel, U. (2016). Foreign Direct Investment via M\&A and domestic entrepreneurship: blessing or curse?. Small Business Economics, 48(3), 599-612.

Davies, R. B., Desbordes, R., and Ray, A. (2015). Greenfield versus Merger \& Acquisition FDI: Same Wine, Different Bottles?. Working Paper 201503, School of Economics, University College Dublin.

De Backer, K., \& Sleuwaegen, K. (2003). Does foreign direct investment crowd out domestic entrepreneurship? Review of Industrial Organization, 22(1), 67-84. https://doi.org/10.1023/A:1022180317898.

De Mello, L. (1999). Foreign direct investment-led growth: Evidence from time series and panel data. Oxford Economic Papers, 51(1), 133-151. https://doi.org/10.1093/oep/51.1.133.

$\mathrm{Fu}, \mathrm{X}$. (2011). Foreign direct investment and managerial knowledge spillovers through the diffusion of management practices. Journal of Management Studies, 49(5), https://doi.org/10.1111/j.1467-6486.2011.01036.x.

Gartner, W. B. (1989). "Who is an Entrepreneur?" is the wrong question. Entrepreneurship Theory and Practice, 13(4), 47-68. https://doi.org/10.1177/104225878901300406.

Gavron, R., Cowling, M., Holtham, G., \& Westall, A. (1998). The entrepreneurial society. London: Institute for Public Policy Research.

Gemmell, N. (1982). Economic development and structural change: The role of the service sector. Journal of Development Studies, 19(1), 37-66

Gopalan, S. Ouyang, A., and Rajan. R. S. (2017). Impact of Greenfield FDI versus M\&A on growth and domestic investment in developing Asia. Economia Politica, 35(1), 41-70.

Gorg, H., \& Greenaway, D. (2004). Much ado about nothing? Do domestic firms really benefit from foreign direct investment? The World Bank Research Observer, 19(2), 171-197. https://doi.org/10.1093/wbro/lkh019.

Goel, R. K. (2018). Foreign direct investment and entrepreneurship: Gender differences across international economic freedom and taxation. Small Business Economics, 50(4), 887- 897. https://doi.org/10.1007/s11187-017-9914-2.

Gromb, D., \& Scharfstein, D. (2002). Entrepreneurship in equilibrium. NBER Working Paper, 9001.

Grossman, G., and Helpman, E. (1991). Trade, Knowledge Spillovers, and Growth. European Economic Review, 35, $517-526$.

Guimón, J. (2009). Government strategies to attract R\&D-intensive FDI. The Journal of Technology Transfer, 34(4), $364-379$.

Harbison, F. (1956). Entrepreneurial organization as a factor in economic development. The Quarterly Journal of Economics, 70(3), 364-379.

Harrison, A. E., \& McMillan, M. (2003). Does direct foreign investment affect domestic firm credit constraints? Journal of International Economics, 61(1), 73-100. https://doi.org/10.1016/S0022-1996(02)00078-8.

Harms, P., \& Méon, P.-G. (2018). Good and useless FDI: The growth effects of Greenfield investment and mergers and acquisitions. Review of International Economics, 26(1), 37-59. https://doi.org/10.1111/roie.12302.

Hennart, J. F., \& Park, Y. R. (1993). Greenfield vs. acquisition: The strategy of Japanese investors in the United States. Management Science, 39(9), 1054-1070. https://doi.org/10.1287/mnsc.39.9.1054.

Hébert, R. F., and Link, A.N. (1989). In Search of the Meaning of Entrepreneurship. Small Business Economics, 1, 39-49. 
Hofstede, G. J., \& Minkov, M. (2010). Cultures and organizations: Software of the mind. New York: McGraw Hill.

Hausman, J., Hall, B., Griliches, Z. 1984 "Econometric models for count data with an application to the patents-R\&D relationship." Econometrica, 52: 909-938.

Javorcik, B. S. (2004). Does foreign direct investment increase the productivity of domestic firms? In search of spillovers through backward linkages. The American Economic Review, 94(3), 605-627. https://doi.org/10.1257/0002828041464605.

Johnson, A. (2006). The effects of FDI inflows on host country economic growth. CESIS Working Paper No. 58.

Jude, C. (2018). Does FDI crowd out domestic investment in transition countries? Economics of Transition and Institutional Change, 27(1), 163-200.

Karlsson, S., Lundin, N., Sjoholm, F., \& He, P. (2007). FDI and job creation in China, (p. 723). IFN Working Paper.

Kaufmann, D., \& Kraay, A. (2007). Governance indicators: Where are we, where should we be going? In Policy Research Working Paper 4370. Washington, DC: World Bank. https://doi.org/10.1596/1813-9450-4370.

Kim, P. H., \& Li, M. (2012). Injecting demand through spillovers: Foreign direct investment, domestic socio-political conditions, and host-country entrepreneurial activity. Journal of Business Venturing, 29, 210-231.

Kim, Y.-H. (2009). Cross-border M\&A Versus Greenfield FDI: Economic Integration and its Welfare Impact. Journal of Policy Modeling, 31(1),87-101.

Kim D-D, Seo J-S. (2003). Does FDI inflow crowd out DI in Korea quest. Journal of Economic Studies, 30, 605-622.

Klapper, L., \& Love, I. (2011). The impact of the financial crisis on new firm registration. Economics Letters, 113(1), 1-4. https:// doi.org/10.1016/j.econlet.2011.05.048.

Knoben, J., Ponds, R., \& Oort, F. V. (2011). Employment from new firm formation in the Netherlands: Agglomeration economies and the knowledge spillover theory of entrepreneurship. Entrepreneurship \& Regional Development - An International Journal, 23(3), 135-157. https://doi.org/10.1080/08985620903183736.

Lankes, R. D. (2011). The atlas of new librarianship. Cambridge, MA: MIT Press. https://doi.org/10.7551/mitpress/8755.001.0001.

Markusen, J. R., and Venables, A. J. (1999). Foreign Direct Investment as a Catalyst for Industrial Development, European Economics Review, 43, 335-356.

Moriano, J. A., Gorgievski, M., Laguna, M., Stephan, U., \& Zarafshani, K. (2012). A crosscultural approach to understanding entrepreneurial intention. Journal of Career Development, 39(2), 162-185. https://doi.org/10.1177/0894845310384481.

Moran, T. (1998). Foreign direct investment and development. Washington D.C.: Institute for International Economics

Muller, T. (2006). Analyzing modes of foreign entry: Greenfield investment versus acquisition. Review of International Economics, 15(1), 93-111.

Munemo, J. (2015). Foreign direct investment, business start-up regulations and entrepreneurship in Africa. Economics Bulletin, $35(1), 1-13$.

Neumann, T. (2020). The impact of entrepreneurship on economic, social and environmental welfare and its determinants: A systematic review. Management Review Quarterly. https://doi.org/10.1007/s11301-020-00193-7.

Norbäck, P. J., \& Persson, L. (2005). Privatization policy in an international oligopoly. Economica, 72(288), 635-653. https://doi. org/10.1111/j.1468-0335.2005.00436.x.

Pathak, S., Laplume, A., \& Xavier-Oliveira, E. (2015). Inbound foreign direct investment and domestic entrepreneurial activity. Entrepreneurship \& Regional Development - An International Journal, 27(5), 334-356. https://doi.org/10.1080/08985626.2015.1058424.

Peris-Ortiz, M, Rueda-Armengot, C, Osorio, D.B. (2012). Women in business: Entrepreneurship, ethics and efficiency. International Entrepreneurship and Management Journal, 8 (3) , 343-354

Poschke, M. (2012). Entrepreneurs out of necessity': A snapshot. Applied Economics Letters, 20(7), 658-663.

Poulsen, L. S., \& Hufbauer, G. C. (2011). Foreign direct investment in times of crisis, (pp. 11-13). Peterson Institute for International Economics Working Paper Series.

Raff, H., Ryan, M., and Stähler, F. (2009). The choice of market entry mode: Greenfield investment, M\&A and joint venture. International Review of Economics \& Finance, 18(1), 3-10.

Rissman, E. R. (2003). Self-employment as an alternative to unemployment, (pp. 2003-2034). Federal Reserve Bank of Chicago Working Paper.

Rodriguez-Clare, A. (1996). Multinationals, linkages, and economic development. American Economic Review, 86(4), 852-873.

Romer, P. M. (1986). Increasing return and long-run growth. Journal of Political Economy, 94(5), 1002-1037. https//doi.org/10.1086/261420

Romer, P. M. (1990). Endogenous technological change. Journal of Political Economy, 98, 71-101.

Rudra, N. (2002). Globalization and the decline of the welfare state in less-developed countries. International Organization, 56(2), 411-445. https://doi.org/10.1162/002081802320005522.

Salgado-Banda, H. (2007). Entrepreneurship and economic growth: An empirical analysis. Journal of Developmental Entrepreneurship, 12(1), 3-29. https://doi.org/10.1142/S1084946707000538.

Solow, R. M. (1956). A Contribution to the Theory of Economic Growth. The Quarterly Journal of Economics, 70(1), 65-94.

Schumpeter, J. A. (1934). The theory of economic development. Cambridge, MA: Harvard University Press.

Schumpeter, J. A. (1942). Capitalism, socialism and democracy. New York: Harper.

Stiebale, J., and Reize, F. (2011). The impact of FDI through mergers and acquisitions on innovation in target firms. International Journal of Industrial Organization, 29(2), 155-167.

Thai, M. T. T., Turkina, E. (2014). Macro-level determinants of formal entrepreneurship versus informal entrepreneurship. Journal of Business Venturing, 29(4), 490-510.

UNCTAD. (1999). Foreign Direct Investment and the Challenge of Development. United Nations Conference on Trade and Development rade and Development, Geneva.

Wu, J., Li, S., \& Selover, D. D. (2012). Foreign direct investment vs. foreign portfolio investment. Management International Review, 52(5), 643-670. https://doi.org/10.1007/s11575-011-0121-0.

Wheeler, D., and A. Mody,\&nbsp;(1992) "International Investment Location Decisions: The Case of U.S. Firms," Journal of International Economics, 33, 57-76.

\section{Publisher's Note}

Springer Nature remains neutral with regard to jurisdictional claims in published maps and institutional affiliations. 